Anna Maria Skibska

\author{
Uniwersytet im. Adama Mickiewicza \\ w Poznaniu \\ anna.skibska@amu.edu.pl \\ ORCID: 0000-0001-9237-8745
}

Data przesłania tekstu do redakcji: 11.02.2019

Data przyjęcia tekstu do druku: 27.05.2019

\title{
Agon literacki w świetle rycerskiego modelu kultury
}

\begin{abstract}
Skibska Anna Maria, Agon literacki w świetle rycerskiego modelu kultury (Literary Agon in the Light of the Knight's Cultural Model). "Poznańskie Studia Slawistyczne" 16. Poznań 2019. Publishing House of the Poznań Society for the Advancement of the Arts and Sciences, Adam Mickiewicz University, pp. 319-337. ISSN 2084-3011.

This essay - actually a scientific article included in the frame composition - is devoted to the innovative interpretation of literary agon in terms of the knight ethos on the background of Harold Bloom's "anxiety of influence", additionally enriched with references to Aeschylus' and Eurypide's "duel" in the Frogs by Aristophanes. On theoretical and methodological ground, the main research path is associated with an additional interpretation of Harold Bloom's idea of intervals.
\end{abstract}

KEYwORDs: literary agon; knight ethos; intervals; Harold Bloom

Wystarczy otworzyć słownik. Walczyć znaczy przeciwstawić swoją wolę woli drugiej osoby, aby ją złamać, rzucić na kolana, w razie czego zabić. „Życie jest walką” to wyrażenie, które, wypowiedziane po raz pierwszy, musiało zabrzmieć jak melancholijne i pełne rezygnacji westchnienie. Naszemu stuleciu optymizmu i rzezi udało się przekształcić to straszne powiedzenie w wesołą piosenkę. Powiecie może, że choć walka przeciw komuś jest niekiedy rzeczą straszną, to walka o coś jest szlachetna i piękna. Z pewnością pięknie jest nie szczędzić wysiłków w służbie szczęścia (miłości, sprawiedliwości itd.), lecz jeśli lubicie określać swoje wysiłki słowem walka, wynika z tego, że w waszym szlachetnym wysiłku kryje się pragnienie, by przewrócić kogoś na ziemię. Walki o nie da się oddzielić od walki przeciw, a podczas walki walczący zawsze zapominają o przyimku $o$ na rzecz przyimka przeciw (Kundera, 1995, 149) ${ }^{1}$.

${ }^{1}$ Kunderowska walka przyimków w doskonały sposób zapowiada agon literacki, w którym trwają zmagania między mistrzami oraz uczniami lub, używając języka Harolda Blooma, 


\section{Zdarzenie inicjalne}

W przywołanej Nieśmiertelności Milana Kundery, spektakularnie spełniającej wymogi formy będącej kontaminacją dwóch energii, powieściowej oraz eseistycznej ${ }^{2}$, fantastyczna kraina podziemi, znana z komedii staroattyckiej, zastąpiona zostaje realistyczno-dyskursywnymi odsłonami, w których czytelnik za sprawą podszytych fikcją fragmentów z życia Johanna Wolfganga Goethego wkracza w przestrzeń wielkiego literackiego kanonu. Spotyka w nim nie tylko autora Cierpień młodego Wertera, w dojrzałym wieku uwikłanego w sentymentalną, quasi-miłosną przygodę z młodą Bettiną Brentano, ale także Friedricha Schillera, Johanna Herdera, Rainera M. Rilkego, Paula Eluarda, wreszcie Ernesta Hemingwaya, którego zadziwiająca, lecz arbitralna obecność ciekawić może najbardziej. W usta amerykańskiego pisarza wkłada bowiem Kundera przygnębiające rozpoznanie odnośnie do tytułowej nieśmiertelności, w pogoni za którą maszeruje spiesznie literatura. Na stanowisko Goethego, bliskie horacjańskiej formule, Hemingway żywiołowo wszak reaguje, powiadając, iż „Zapewne wkrótce nie będzie się już czytać naszych książek. Po pańskim Fauście pozostanie ta głupawa opera Gounoda. No, może jeszcze ten wiersz, w którym mowa o wiecznej kobiecości... Za to ludzie nigdy nie przestaną obgadywać szczegółów z pańskiego życia, nawet tych najdrobniejszych" (Kundera, 1995, 206-207). Goethe tymczasem, w próbie „stoickiej” riposty na cytowane dictum, odsłania się jako orędownik ponadludzkiej i ze wszech miar elegijnej „obojętności wobec własnego wizerunku”, do której

między prekursorami a adeptami sztuki literackiej: ci ostatni, walcząc o własną podmiotowość, wystąpić muszą przeciwko prekursorom, na których dziełach się wzorują (Bloom, 2002, 76 i n.).

${ }^{2} \mathrm{Na}$ temat struktury powieściowej książek Kundery, wypracowanej w oparciu o dzieła starych, premodernistycznych mistrzów, ciekawie piszą autorzy jego polskich przekładów. Marek Bieńczyk, za François Ricardem, eksponuje rolę elipsy, determinującej intencjonalną fragmentaryczność tekstów czeskiego pisarza (Bieńczyk, 2012, 412-413), ale także podnosi problematykę przemocy przezroczystości opisywaną w eseistycznej Sztuce powieści (Bieńczyk, 2015, 86-88), Jacek Illg z kolei nazywa Kunderowską powieść ,ppolihistoryczną”, w której dominuje poetyka kondensacji, niemożliwa do skonstruowania bez pracy eliptycznej detrakcji, warunkującej z kolei technikę muzycznego w proweniencji kontrapunktu: ,jak warunkiem kontrapunktu muzycznego jest równoważność poszczególnych głosów, tak nieodzownym warunkiem kontrapunktu powieściowego jest dla Kundery równoważność poszczególnych elementów oraz niepodzielność całości” (Illg, 1990, 97). 
zobowiązuje skończoność materii ożywionej, czy, mówiąc prościej, bycie istotą śmiertelną. $Z$ tym przecież byciem najmniej, jak wielokrotnie podkreśla Kundera, potrafimy się obchodzić. Nie zamierzając zrezygnować z wcześniej zamanifestowanej pozycji, Goethe w sposób, wydaje się, rozstrzygający (miejsce wyrazistego autotematyzmu spod znaku Sterne'a) konkluduje: „Niechże pan nie robi z siebie durnia, Erneście. Wie pan dobrze, że jesteśmy w tej chwili jedynie frywolnym wymysłem jakiegoś powieściopisarza, który każe nam mówić to, co sam chce powiedzieć i czego zapewne sami nie powiedzielibyśmy nigdy. Dajmy zresztą temu spokój” (Kundera, 1995, 208).

W rozmowach przywoływanych mistrzów przewija się demoniczna instytucja wiecznego procesu, w którym na ławie oskarżonych zasiadać mają twórcy wielkiego kanonu, wydani na pastwę komentarzy potomnych. W sercu owej instytucji tkwi niepochwytna istota literatury, której immanentna skłonność do eliptycznego zawieszania samej siebie, zbieżna $\mathrm{z}$,umiłowaniem” transgresji, determinuje jej ciągły rozwój, nawet jeśli toczy się on jednocześnie pod auspicjami przeraźliwego pawiego krzyku ze znanego wiersza Wallace'a Stevensa ${ }^{3}$. Literatura stanowi arenę niemających kresu walk odbywających się między mistrzami oraz adeptami, przy czym wysiłki tych ostatnich, stojących u bram wielkiego kanonu, szczególnie dobrze ilustrują opowiadaną w motcie fuzję przyimków: adepci w walce o własną oryginalność wystąpić muszą przeciwko prekursorom, z których porywającego, inspirującego idiomu rodzi się pragnienie pisania. Pragnienie to wyrasta jednak przede wszystkim z pożądania nieśmiertelności, jakiej dostąpić mogą wyłącznie ci, którzy w drodze retorycznego wmówienia sobie twórczej siły potrafią wybić się na podmiotową niepodległość ${ }^{4}$. Niechybnym dowodem owej literackiej autonomii jest brawuro-

\footnotetext{
${ }^{3}$ Mam na myśli jeden z wczesnych wierszy Stevensa (1997, 7), Domination of Black, pochodzący z debiutanckiej książki poetyckiej zatytułowanej Harmonium (1923). Powracający w nim pięciokrotnie temat krzyku pawi (the cry of the peacocks) świetnie ilustruje atmosferę lęku przed naporem literackiej tradycji, której przeciwstawić się musi młody adept poezji. Wiersz ten jest dostępny w polskim przekładzie, w którym otrzymuje tytuł Dominacja czerni (Stevens, 2008, 5).

${ }^{4}$ „Albowiem każdy poeta zaczyna (jakkolwiek «nieświadomie») od - silniejszego niż w przypadku zwykłych ludzi - buntu przeciwko nieuchronności śmierci. Młody obywatel republiki poezji [...] jest od początku człowiekiem antynaturalnym i antytetycznym, i od początku poszukuje niemożliwego, podobnie jak kiedyś jego prekursor” (Bloom, 2002, 54).
} 
we podcinanie zastanego dziedzictwa, dokonywane przy użyciu różnych metod i narzędzi, w którym jednakowoż liczy się nie tyle demolowanie tradycji, ile jej „niewłaściwe”, twórcze odczytywanie.

\section{Misreading albo afirmacja błędnej interpretacji ${ }^{5}$}

Poets tend to think of themselves as stars because their deepest desire is to be an influence, rather than to be influenced, but even in the strongest, whose desire is accomplished, the anxiety of having been formed by influence still persists (Bloom, $2003,13)^{6}$.

Kategoria błędu należy do konstytutywnych wykładników teorii lęku przed wpływem, od dziesięcioleci lansowanej przez Harolda Blooma, która w opinii swojego prawodawcy pozwala rozpoznać „właściwe” oblicze literatury, czerpiącej niegasnącą energię z kilku zabiegów rewizyjnych, determinujących układ sił między dziełami prekursorów a utworami adeptów. Przed krótką charakteryzacją tychże zabiegów warto jednak stawić czoła trzem założycielskim twierdzeniom, w których dostrzec można dyskretną obecność fundatorów Bloomowskiego idiomu, czyli Nietzschego oraz Freuda ${ }^{7}$. Pierwsze twierdzenie sprowadza się do utożsamienia dziejów

${ }^{5}$ Wypracowany przez dekonstrukcjonistów amerykańskich (słynna „,szkoła z Yale”) termin misreading ma dwie różne wykładnie interpretacyjne, choć obie pozostają w ścisłym związku z ironią. W optyce Blooma strategia błędnego odczytania dzieła prekursora przez młodego twórcę jest wyrazem walki o indywidualną pozycję w historii literatury, jak i stanowi fundament rozwoju tejże literatury. Stanowisko Paula de Mana, zdecydownaie bardziej lingwistyczne i promujące określoną, negatywną fillozofię języka, pojęcie misreading wiąże z materialnością językowego tworzywa, ujawnianą dzięki pracy ironii rozbijającej koherencję tekstu i uniemożliwiajacej jego konwencjonalne odczytanie. W efekcie uprawiana przez de Mana dekonstrukcja zasadza się na kontaminacji ironii jako permanentnej parabazy alegorii (ironii odziedziczonej po Friedrichu Schleglu) oraz kontynuowanej za szkołą New Criticism taktyki close reading (de Man, 2004, 22-30; 1999a; b).

${ }^{6} \mathrm{~W}$ A Map of Misreading, z której pochodzi przywołane wyżej motto, Bloom dokonuje redukcji lęku przed wpływem do strachu przed śmiercią (the fear of death), z czego wnioskuje, że poetyckie wyglądanie nieśmiertelności (the vigilance of immortality) tożsame jest z uwolnieniem się od wpływu. Krytyk zestawia także ów lęk z doświadczeniem zazdrości, które pociąga za sobą problematykę cielesności zamieszkiwanej przez twórczą wyobraźnię w jej posiadaniu zaś znajduje się jedynie jej własna śmierć (Bloom, 2003, 198-199).

${ }^{7}$ Twórca How to Read and Why wyznaje, że ,największy wpływ na teorię wpływu przedstawioną w tej książce wywarli Nietzsche i Freud. Nietzsche jest prorokiem tego, co 
literatury z wpływem literackim, jako że umożliwia on ów ruch błędnego odczytywania jednych twórców przez drugich, służący „oczyszczaniu pola wyobraźni”, zorientowanej odtąd na własną, indywidualną biografię artystyczną. Historia literatury ma sens, podkreśla po wtóre Bloom, gdy oznacza obcowanie $\mathrm{z}$,wybitnymi postaciami, którym starcza wytrwałości, by zmagać się z prekursorami nawet, jeśli grozi to śmiercią” (Bloom, 2002, 49). Po trzecie zaś, dokonujące się na drodze misreading przywłaszczanie literackiej tradycji tylko wtedy zasługuje na uznanie, gdy wywołuje „,przejmujący lęk przed zadłużeniem”, który w sposób nadrzędny stymuluje rozwój suwerennej podmiotowości twórczej.

W pojedynczej historii owej podmiotowości, konsekwentnie rozwijanej w kierunku nieśmiertelności, Bloom przewiduje obecność sześciu interwałów, bez których okrutna rywalizacja z prekursorami nie ma szans na powodzenie. Pierwszym z nich jest clinamen, gest sankcjonujący błąd, zmianę czy, dosłownie (za Lukrecjuszem ${ }^{8}$ ), „odchylenie” od mistrzowskiego idiomu w celu poszukiwania nowego kierunku w artystycznej biografii adepta, pragnącego zerwać z groźbą epigonizmu streszczającego się w powtórzeniu. Opracowane przez heretyckiego Lukrecjusza zjawisko wiąże się również z Epikurejską teorią nieoznaczoności, zwaną paraklizą, warunkującą między innymi przeświadczenie o istnieniu wolnej woli, która występuje poza porządkiem teleologicznym i w swojej nieprzewidywalności

antytetyczne, a $Z$ genealogii moralności to najgłębsze znane mi studium rewizjonistycznych i ascetycznych rysów temperamentu estetycznego. Z kolei Freudowskie mechanizmy obronne i ich ambiwalentna natura stanowią najbliższą analogię do zabiegów rewizyjnych, rządzących relacjami wewnątrzpoetyckimi” (Bloom, 2002, 52).

${ }^{8}$ Legendarna postać Lukrecjusza (właściwie Titusa Lucretiusa Carusa) wiąże się przede wszystkim z jego heretyckim epikureizmem zaprezentowanym w poetyckim traktacie kosmogonicznym zatytułowanym $O$ naturze rzeczy (względnie $O$ rzeczywistości), w którym autor brawurowo rozprawia się z politeistycznym mitem starożytności i opowiada się za atomistyczną teorią powstania wszechświata (v. Korpanty, 1991; Gudaniec). „Zgodnie z nauką Epikura, Lukrecjusz przyjmował w teorii poznania koncepcję «simulacra», tj. obrazów ułożonych z atomów, które emanują od przedmiotów, docierając przez zmysły do intelektu (do atomów mózgu). Poeta kładł mocniejszy akcent na wykorzystanie teorii «clinamen» [...], tj. odchylenia spadających atomów od linii pionowej, wyznaczonej ich naturalnym ruchem. Takie nieokreślone skrzywienia ruchu atomów miały tłumaczyć indeterminizm spotykany w naturze, zwłaszcza w przypadku wolnej woli człowieka. Jest to jeden z przykładów charakterystycznego dla Lukrecjusza dążenia do tego, by znaleźć naturalistyczne wyjaśnienie każdego faktu z dziedziny życia osobowego i społecznego" (Grabarczyk, 2013). 
jawi się wydarzeniem czystej inwencji ${ }^{9}$. Adam Lipszyc wiąże omawiany fenomen z tropem ironii, dokonującej wyłomu w tradycji, w wyniku którego rozpoczyna się wyczerpujący bieg adepta zmuszonego w pewnym subiektywnym momencie wziąć w nawias telos, ku jakiemu zmierza tekst prekursora $^{10}$. Nie ulega jednak wątpliwości, że z chwilą zaistnienia tajemniczego (zwłaszcza jego źródłowość jest nienamacalna) zjawiska clinamen otwiera się perspektywa literackiego agonu, wezwania do rywalizacji, w której między antagonistami toczy się walka na śmierć i życie, świetnie zilustrowana opowiadaną w Strachu przed kontaminacja historią Christophera Marlowe'a połkniętego przez Szekspira niczym biblijny Jonasz przez wielką rybę ${ }^{11}$.

${ }^{9} \mathrm{O}$ współczesnych rozwinięciach teorii Epikura intrygująco pisze Michael James Bennett $(2013,131-157)$.

${ }^{10}$ „Dla Blooma - inaczej niż dla de Mana - ironia jest tropem i to tropem tropów, ponieważ stanowi paradygmatyczne odchylenie od znaczenia dosłownego, które wszak charakteryzuje wszystkie tropy retoryki. Jeżeli więc - jak głosi główna teza teorii Blooma - życie poety polega na zmaganiach się $\mathrm{z}$ lękiem przed wpływem, a bronią w tej walce są tropy retoryczne, ironia musi być pierwszym tropem, pierwszym odejściem od znaczenia dosłownego, pierwszym krokiem samodzielnego poety, który nie chce być tylko bladą odbitką prekursora. Tak więc Bloom wiąże trop ironii z fazą clinamen, pierwszą z sześciu faz, w ramach których poeta walczy ze swym lękiem. Ironia jest tu z pozoru pojmowana dość tradycyjnie jako trop, w którym mówi się jedną rzecz, a ma się na myśli inną - w szczególności wprost przeciwną. Dodatkowo, zgodnie ze swoją zasadą tożsamości tropów i Freudowskich technik obronnych, Bloom łączy ironię z jedną z obron wyróżnionych przez ojca psychoanalizy, a mianowicie $\mathrm{z}$ Reaktionobildung, czyli formacją reaktywną. Jak wiadomo, jest to jedna z najbardziej podstawowych technik obronnych. Polega ona na tym, że na poziomie świadomości pojawia się reakcja dokładnie odwrotna do tej, do jakiej prze nieświadomy popęd. Typowym przykładem jest sytuacja, w której matka podświadomie pragnąca śmierci swojego dziecka otacza go nadmierną, przytłaczającą opieką. Tak wiec analogia, jaką przeprowadza Bloom pomiędzy ironią a formacją reaktywną, jest stosunkowo dokładna i zauważalna" (Lipszyc, 2006, 253).

${ }^{11}$ „Marlowe jest tak daleki od wiernego przedstawienia ludzkiego charakteru i osobowości, że kiedy porównujemy go z dojrzałym Szekspirem, wydaje sie groteskowy. Podobnie jak Edmund z Króla Leara (będący czymś w rodzaju szekspirowskiego sądu ostatecznego nad Marlowem), ani sam Marlowe, ani jego protagoniści nie przejawiają niczego, co przypominałoby ludzkie uczucia. [...] Szekspir rzuca w kierunku Marlowe’a ostatnie, szelmowskie spojrzenie w Królu Learze, kreując postać Edmunda, najzimniejszego z wszystkich szekspirowskich drani. Jeszcze długo po zakończeniu egzorcyzmów Szekspir posługiwał sie wzorem bohatera-złoczyńcy (który w Ryszardzie Trzecim jest jeszcze kopią postaci marlowiańskich, ale już w Makbecie zupełnie ich nie przypomina). Nie ulega wątpliwości, że Biblia oraz dzieła Owidiusza i Chaucera wywarły większy wpływ na Szekspirowski sposób tworzenia postaci, ale tylko Marlowe wzbudzał w Szekspirze ambiwalentne uczucie lęku" (Bloom, 2002, 
Kolejnym krokiem rewizyjnym jest zabieg zwany tessera, realizowany przy pomocy dwóch zintegrowanych ze sobą czynności, wiodących ku antytetycznemu dopełnieniu dzieła prekursora przez adepta. W świetle tego podwójnego gestu korekta dokonywana przez walczącą o autonomię podmiotowość otwiera się na spekulację sugerującą niedoskonałość dzieła mistrza, domagającego się w związku z tym wskazanego przekształcenia. Warto podkreślić, że Bloom dokonuje znamiennej reinterpretacji tropu, na który się powołuje - korzysta wszak z rozpowszechnionej przez Gadamera opowieści o tessera hospitalis, rozbitych częściach skorupy (lub jaja) pojmowanych jako starożytny paszport i w Aktualności piękna stanowiących podstawę definicji symbolu (Gadamer, 1993). Z kolei u Blanchota opisywany trop implikuje istotę relacji bez zależności, która jest esencją przyjaźni ukonstytuowanej na zachowaniu dystansu wobec innego (tu: prekursora), leżącej poza wszelką tematyzacją: przedmiotem napiętej uwagi jest w tej optyce doświadczenie samej relacji, gdy wzniosłość i kontrwzniosłość spotykają się w różnicy (Blanchot, 2004).

Trzeci etap literackiego agonu wznosi się na akcie kenosis, który pozostając w semantycznej relacji do swej biblijnej proweniencji, oznacza anihilację ciągłości, $\mathrm{z}$ tą chwilą rozpoczyna się bowiem skomplikowany stosunek mistrza oraz ucznia ${ }^{12}$. Bloom eksplikuje przebieg owego procesu w ten oto sposób:

Poeta późniejszy, z pozoru wyzbywając się natchnienia, swej wyobrażonej boskości, korzy się - zupełnie jakby przestawał być poetą. Dokonuje tego jednak w taki sposób, że strąca z piedestału także prekursora, dzięki czemu późniejszy wiersz nie jest świadectwem aż tak zupełnej pokory, jak mogłoby się wydawać (Bloom, 2002, 58).

Etap kenosis uświadamia zatem, że agon literacki zawiera w sobie wiele $\mathrm{z}$ gry pozorów i meandrujących uników, pozwalających w przebiegu

28-29). W innej książce, nieodmiennie dedykowanej kanonowi literackiemu, amerykański krytyk formułuje ciekawą tezę o wyżej przywoływanym Jonaszu, który w optyce tej tezy stanowi parodię Jeremiasza (Bloom, 1991, 22-24).

${ }^{12}$ Kenoza (z grec. kénōsis, czyli ogołocenie) w teologii chrześcijańskiej dotyczy problematyki wcielenia, interpretowanego jako dobrowolne, zbawcze uniżenie się Chrystusa przejawiające się w rezygnacji z boskości. W innej optyce, bliższej literackiemu agonowi, można w kenozie ujrzeć realizację aktu rywalizacji między boskością a człowieczeństwem. Intencjonalne wyzbycie się boskości implikuje także opartą na kenozie etykę, skoncentrowaną wokół fenomenu samopoświęcenia (v. Oord, 2010). 
walki o artystyczną niepodległość ujrzeć swego rodzaju analogię do skomplikowanej taktyki wojennej, gotowej korzystać z komplementarnych strategii ofensywno-defensywnych, w której zmieniają się przyczółki, szyki zaś zwierają się w coraz to nowych miejscach. Ostatecznie, w związku $\mathrm{z}$ poczynioną analogią, można by historię literatury skonfrontować z makietą permanentnie wędrujących fortyfikacji.

Zabieg czwarty, związany z koniecznym wmawianiem sobie twórczej siły, Bloom nazywa demonizacją i lokalizuje ją w kręgu dziedzictwa neoplatońskiego ${ }^{13}$, zakładającego wiarę $\mathrm{w}$ istnienie pośredniej instancji, która

wnika w duszę adepta, by mu pomagać. Późniejszy poeta otwiera się na moc, którą zaczyna oddzielać od osoby rodzica i postrzegać jako należącą do sfery istniejącej poza prekursorem. Dokonuje tego we własnym wierszu, sytuując go wobec wiersza macierzystego w taki sposób, by uogólnić i zatrzeć oryginalność tego drugiego (Bloom, 2002, 58).

Ową neoplatońską inspirację można skojarzyć także z sokratejskim daimonionem, którego eksplikacja zakłada intelektualno-estetyczną rywalizację między adeptem a prekursorem - w jej burzliwym centrum rodzi się wszak podmiotowy składnik osobowości twórczej. Zagmatwany, żeby nie powiedzieć aporetyczny, charakter daimoniona przybliżają następujące frazy:

To „coś” jest - a może tylko wydaje się - czymś innym od podmiotu, a przecież wynurza się jakby z wnętrza podmiotu. Jest więc czymś niepokojąco dwoistym. Jest czymś „obcym”, a jednocześnie stanowi jakąś istotną cząstkę naszej osobowości. Może więc być rozpatrywane na oba sposoby: albo jako coś „obcego”, co w rezultacie interioryzacji (przyswojenia) stało się czymś „własnym”, albo jako coś „własnego”, co się z nas wyobcowało (wyalienowało) i wydaje się nam czymś obcym, niezwykłym, cudownym, boskim, „daimonicznym” (Pycka, brw.) ${ }^{14}$.

${ }^{13}$ Zainteresowanie owym dziedzictwem wiąże się u Blooma z fascynacją gnostycyzmem oraz kabałą, szczególnie dobrze widoczną w eseju poświęconym relacjom między literaturą a nieortodoksyjnym mistycyzmem żydowskim (v. Bloom, 1975).

${ }^{14}$ „Intuicyjna wiedza o związkach dezintegracji psychicznej z twórczością i unikalnymi talentami czy osiągnięciami wyrażana była już w antyku, kiedy to uważano, że poeci - jedyna zresztą grupa artystów, którym przypisywano zdolności twórcze - są owładnięci niekiedy «boskim szałem». Starożytni uważali zresztą, że w każdej istocie ludzkiej znajduje się «daimonion», rodzaj siły skłaniającej ludzi ku samopotwierdzeniu, który może przejawiać się jako agresja, nienawiść czy okrucieństwo, ale też może być czynnikiem pozytywnym i twórczym. Pozytywny «daimonion» może przejawiać się w kreatywności (poety), religijności 
Demonizacja godzi w prekursora, osłabia jego moc, ukazuje w złym świetle, działa zatem zgodnie z retoryką napiętnowania bądź oszczerstwa, współgrającą z efektami parodystycznej karykatury. Uwikłanie z kolei daimoniona w problem alienacji pozwala na dalsze rozwinięcie Bloomowskiej rewizji.

Demonizacja wiedzie ku kolejnemu gestowi, czyli askesis, która dotyczy zarówno dzieła prekursora, jak i adepta. W polu semantycznym tego pojęcia, pierwotnie oznaczającego ćwiczenie duchowe bądź medytację, wprowadza Bloom mechanizmy samooczyszczenia oraz separacji, służące osiągnięciu „stanu doskonałej samotności”, w której czytelnik traci z oczu wszelkie związki, jakie łączyć by mogły twórczość naszych antagonistów. Etap askesis prowizorycznie zawiesza agon literacki i oferuje iluzoryczną perspektywę Leibnizowskich monad, samotnych wysp dryfujących na oceanach literatury ${ }^{15}$. W kontradykcji do askesis stoi jednak ostatni zabieg rewizyjny, zwany apophrades, oznaczający zaś z odległej perspektywy antycznych Aten ponury i groźny powrót zmarłych, który jednak w wypadku doskonale samotnego poety, twórcy tak spełnionego jak Kunderowski Goethe, stanowi ponowne wejście w relację z dziełem mistrza. Wyjaśniając niecodzienność tej sytuacji Bloom sięga po metalepsis, retoryczną figurę,

oraz miłości [...]. Grecy rozumieli i odczuwali «daimoniona» jako władzę losu, coś, co kieruje człowiekiem z zewnątrz, wyposaża go jednak w zdolności i możliwości, których nie mógłby uzyskać inaczej" (Bobryk, 2011).

${ }^{15}$ Bloom pomniejsza znaczenie zagadnienia askesis najbliższego jego greckiej etymologii, czyli właśnie pojmowania go jako ćwiczenia duchowego, ale jego waga wydaje się nadal aktualna, o czym przekonują ostatnie wykłady Michela Foucaulta z lat 1982-1984 w Collège de France, opowiadające o sztuce samoformowania się myśliciela. Obrazują one także skomplikowane relacje zachodzące między czynnością myślenia a wewnętrzną transformacją „,in his lectures [...] Foucault shows that Western culture has developed two different forms of the relation between the subject and the truth: «spirituality» and «knowledge». Ancient philosophy was fundamentally a mode of spirituality. According to Fouacult, a historical break allowed the «knowledge» model to displace spirituality as the structure of philosophical truth. The historical event of this displacement is what Foucault in 1982 names the «Cartesian moment». In the Meditations we experience the coming to pass of this event. In other words, the Meditations are part of that event by which the subject is detached from spiritual practice as the ground of its access to the truth. As result of this event, access to the truth no longer requires ascetic self-transformation, rather, it requires employing the proper method of reasoning. According to this new way of thinking, this new mode of perceiving oneself as a thinking being and of perceiving the world as a something to be known, self-transformation no longer appears to be necessary in order for one to have access to the truth" (Mc Gushin, 2007, 192). 
która realizuje się poprzez odwrócenie porządku przyczynowo-skutkowego, uprzednio zdekonstruowanego przez przenikliwego twórcę Zaratustry ${ }^{16}$. W konkluzji autor The Western Canon stwierdza: „Ostateczny rezultat rewizji jest niesamowity: nie wydaje nam się już, że to prekursor napisał wiersz adepta, lecz - przeciwnie - że to późniejszy poeta stworzył najbardziej charakterystyczne dzieła prekursora"(Bloom, 2002, 59). Podszyty tajemniczymi i mrocznymi zdarzeniami dionizyjski obrzęd Plynteriów, w czasie którego dochodzi do apophrades, oznacza tkwiącą we wnętrzu dojrzałego artysty potrzebę kreowania własnych mistrzów ${ }^{17}$. Potrzebę, której namiastki dostarcza na początku tej eseistycznej przechadzki Kundera.

Powściągliwa rekonstrukcja rewizjonistycznej maszynerii wiąże się, rzecz jasna, z intencją oświetlenia agonu literackiego, determinującego rozmaite procesy historycznoliterackie. Bloom oferuje nam współczesną wersję romansu rodzinnego, w którym atawistyczne nadwyżki popędowe podporządkowują się zgodnej z Freudowską Lustprinzip figurze substytu$\mathrm{cji}^{18}$. Pod jej auspicjami odbywa się transfer między przyjemnością dionizyjską a jej wyrafinowaną wersją apolińską, którą uosabia sublimacja. Ale antyczny wzorzec literackiej rywalizacji wyrasta, jak wkrótce zobaczymy, z pierwotnej, żywiołowej ludyczności, w której rozstrzygający głos ma nie kto inny, tylko „utrudzony” aurą Bachanaliów bóg śmiechu oraz wina.

\section{W podziemnej krainie Arystofanesa}

Jedną z najbardziej znanych scen założycielskich dotyczących agonu literackiego jest retoryczny pojedynek toczony w fantastycznych zaświatach $\dot{Z} a b$ między fundatorami greckiego dramatu, Ajschylosem oraz Eurypidesem. Rywalizacja dotyczy, oczywiście, dwóch form dramatycznych,

\footnotetext{
${ }^{16}$ Jako figura retoryczna metalepsis (z grec. metálēpsis, czyli zamiana) stanowi odmianę metonimii, w której nazwa przyczyny zastępuje nazwę skutku (Sławiński, 2000, 303).

${ }^{17}$ „Bloom's celebrated «theory of poetry» is altogether a sort of theory of apophrades writ large, since it is fundamentally concerned with poetry (or «great writing») as an encounter with the dead, with the ghostliness of ancestral voices and intertextual hauntings" (Royle, 2003, 147).

${ }^{18}$ Lustprinzip, czyli ,zasada przyjemności” jest, zdaniem Freuda, podstawowym mechanizmem regulującym kulturę, religię oraz życie społeczne, które są produktami nadwyżek popędowych determinujących wszelkie ludzkie działania (Freud, 1998, 175-177).
} 
spośród których pierwsza, prekursorska i kanoniczna, w inicjalnych partiach agonu znajduje się w sytuacji odwrotu pod naporem zrewolucjonizowanej, realistyczno-psychologicznej wersji, będącej dziełem adepta. Rozwiązanie na korzyść prekursora, ostatecznie wychodzącego zwycięsko z owej walki, wiąże się, zgodnie z powszechnym historycznoliterackim komentarzem, z osobistymi preferencjami estetycznymi Arystofanesa, stawiającego na triumfalną, zbawczą moc tradycji ${ }^{19}$. Za sprawą boskiego arbitra, w którego wciela się sam Dionizos, adept Eurypides ustępuje pola mistrzowi Ajschylosowi - jego spektakularna wiktoria staje się kamieniem węgielnym kładzionym pod kanoniczny gmach literatury. Agon, zaprezentowany przez wirtuoza komedii staroattyckiej, ucieleśnia bitwę o sławę, w której pierwszeństwo stanowi pewniejszą gwarancję nieśmiertelności. Uzasadnienie zwycięstwa Ajschylosa w zainscenizowanym przez Arystofanesa fantastycznym pojedynku płynie między innymi z tego oto komentarza:

Nastrój dramatu jest nastrojem dionizyjskiej ekstazy, odświętnego upojenia i dytyrambicznego zachwytu, aktor zaś, wyniesiony dla publiczności ponad świat codzienny, czuje się wśród tego entuzjazmu dzięki masce, jaką nosi, wyobcowany w inne ,ja", którego już nie przedstawia, lecz które uprzytamnia i urzeczywistnia. W sferę tych uczuć porywa słuchaczy. Potęga niezwykłych słów, niebywałość obrazowania i wyrazu są u Ajschylosa w całkowitej zgodzie z sakralnością gry: wyrastają z sakralności ludycznej (Huizinga, 1998, 244).

Kiedy Bloom w swojej słynnej elegii artykułowanej pod adresem kanonu powiada, że wszystkich nas wymyślił Szekspir, odsłania bolesną konieczność uświadomienia sobie owej belatedness, kondycji opóźnienia, w której żelaznych okowach wszyscy się znajdujemy: współtworzą nas prekursorzy, co oznacza jeszcze dalej idącą konsekwencję, zbieżną z rozpoznaniem, iż bez nich bylibyśmy nikim ${ }^{20}$. Pozostaje nam zatem strategia

${ }^{19}$,W Eurypidesie widzi on [Arystofanes - A.M.S.] destruktora podstaw psychicznych, na których opierała się dawna wielkość Aten, i destruktora tragedii jako rodzaju sztuki monumentalnej, któremu właścią formę nadał Ajschylos. [...] Arystofanes zwalcza Eurypidesa zarówno od strony ideologicznej, jako propagatora myśli «meteorologów» i sofistów, wroga religii $[\ldots]$ i tradycyjnej moralności, jak też i od strony artystycznej. Gromi go za zniekształcenie stylu tragedii retoryką i sofistycznymi dyskusjami [...]. Wyśmiewa jego tendencję do wprowadzania do tragedii rzeczy zwykłych, poziomych, wziętych z życia codziennego i nie licujących z jej monumentalnym stylem" (Srebrny, 1955, 41).

${ }^{20}$,[W]e cannot rid ourselves of Shakespeare, or of the Canon that he centers. Shakespeare, as we like to forget, largely invented us; if you add the rest of the Canon, then 
sprytnego Ulissesa, który demonstrując znany unik oswabadzający go z więzienia Polifema, podpowiada nam grę z czasem, tak dobrze widoczną w strategii apophrades. Agon antyczny, którego tematyzację spotykamy w Żabach, nie stanowi li tylko motywu kulturowego, wywiedzionego z głębi antycznej cywilizacji. Przeciwnie, bierze on udział w formalnych aspektach komediowego teatrum, zrodzonego z ludycznego kultu Dionizosa, niemożliwego do pomyślenia bez zjawiska wznoszącej się na dialogu satyry. W komedii spod znaku Arystofanesa dwie zasadnicze części kompozycyjne, czyli agon oraz parabaza, stanowią kontaminację attyckiej komedii chóralnej oraz doryckiej krotochwili, która przełamuje obligatoryjną obecność dwóch rywalizujących ze sobą chórów na rzecz aktorów-solistów, tym zaś może, jak ma to miejsce w Ptakach, towarzyszyć trzecia postać, błazna czy wesołka, „który nie bierze udziału w dyskusji, lecz tylko komicznie ją komentuje na marginesie w stałym kontakcie z widzem" (Srebrny, 1955, 13). Owa trzecia postać spełnia misję ironisty, który za sprawą gestu parabazy podcina koherencję właściwej akcji, eksponując tym samym jej fikcjonalny charakter ${ }^{21}$. Ta właśnie misja będzie miała

Shakespeare and the Canon wholly invented us. [...]. We owe to Shakespeare not only our representation of cognition but much of our capacity for cognition. The difference between Shakespeare and his nearest rivals is one of both kind and degree, and that double difference defines the reality and necessity of the Canon. Without the Canon, we cease to think. You may idealize endlessly about replacing aesthetic standards with ethnocentric and gender considerations, and your social aims may indeed be admirable. Yet only strength can join itself to strength, as Nietzsche perpetually testified" (Bloom, 1995, 40-41).

"Readers will note the recurrence in these pages of many familiar ghosts of poststructuralism - Freud, Lacan, Derrida, Marx, de Man, and Nietzsche - alongside Thomas More, Samuel Johnson, A.C. Bradley, and Superman comic books. Why the emphasis upon the canonical figures of postmodernism and poststructuralism? Because, once again, what interests me is the uncanny extent to which these writers are themselves haunted by Shakespeare, the way in which Shakespearean texts - and especially the most canonical texts of Shakespearean tragedy - have mined themselves into the theoretical speculations that have dominated our present discourses, whether in literature, history, psychoanalysis, philosophy, or politics" (Garber, 2010, xxiii-xxiv).

${ }^{21} \mathrm{~W}$ świetle antagonizmu, jaki charakteryzować miał stosunek Arystofanesa do Sokratesa, dziwić może ważna funkcja błazna-ironisty jako krytycznego komentatora przedstawianych zdarzeń komediowych. Autorstwo parabazy (aluzji bądź dygresji), umożliwiającej manifestację tej funkcji, przypisuje się właśnie twórcy Ptaków, którego heterogeniczny model komediowy jest też głównym źródłem inspiracji dla Friedricha Schlegla i jego swoistej ironii romantycznej, przejawiającej się w „,permanentnej parabazie” oraz „transcendentalnej błazenadzie”. O tej pierwszej można przeczytać, że ,przypomina wręcz o tym, że prawdziwa 
wiele, jak świetnie wiadomo, rozwinięć tak w przestrzeni literatury, jak i w filozoficznych dyskursach.

\section{Literacki agon a etos rycerski - koniunkcje i dysjunkcje}

Muszą więc istnieć zarodki o ciele wolnym od śmierci, By w chwili ostatniej wszystko mogło się na nie rozpraszać

I tak dostarczać materii rzeczom na nowo tworzonym. (Carus, 1994).

Johan Huizinga w swoim znanym studium zatytułowanym Homo ludens za pomocą licznych odwołań i komparatystycznych analiz dowodzi sakralno-ludycznych korzeni wielu podstawowych dyscyplin, formowanych od czasów wspólnot archaicznych. Najbardziej wyrazistym elementem owej przeszłości jest fenomen rywalizacji, umożliwiający pełną i wielowymiarową introdukcję wątku agonalnego (agonicznego), uobecniającego się na rozmaitych poziomach życia społeczno-kulturowego, wątku w najczystszej postaci rozpoznawalnego właśnie w owych odległych, archaicznych realizacjach. Nie ulega zatem wątpliwości, że determinować on będzie zarówno formy antycznej strategii wojennej, jak i genera dicendi, z których dziedzictwa czerpią wszelkie późniejsze zdarzenia literatury, nie wspominając o innych dziedzinach ludzkiej kulturotwórczej aktywności. Sakralny charakter gry bądź zabawy, wpisujący się w strukturę agonu, w swoim najbardziej żywotnym, oryginalnym kształcie zrealizować się może wyłącznie w takim doświadczeniu wojny, która uprawiana jest $\mathrm{w}$ granicach rygorystycznie przestrzeganych zasad. Najczęstszą w tym wypadku analogią, potwierdzaną przez Huizingę, są szachy definiowane jako wojna, w której zwycięża się siłą rozumu (Huizinga, 1998, 95).

$\mathrm{Na}$ tym tle warto byłoby zaryzykować nową także definicję literatury postrzeganej odtąd jako wojna, w której zwycięża się siłą talentu i twórczej inwencji. Dają one początek kodeksowi kanonicznych wartości

sztuka romantyczna musi być związana z przekraczaniem rzeczywistości, że rodzić się może tylko tam, gdzie idee i realność wchodzą we wzajemny związek. Parabaza taka przypomina autorowi, że jest autorem, a nie cudotwórcą, że literatura jest sztuką, a nie religią. Wychylanie się artysty ze swego dzieła miało charakter autoprezentacji” (Szturc, 1992, 184). 
odzwierciedlanych w normach i etykiecie dworskiej kultury średniowiecza. Turniej rycerski należy do najlepszych przykładów, w jakich przejawia się kontynuacja idei wojny archaicznej, która krzepnie w wymiarze kulturowego obyczaju, konserwuje repertuar szlachetnych postaw i konwencjonalnych zachowań, porządkujących klarowny paradygmat rycerskiego świata, sferę inicjalnej sakralności ludycznej redukując przy tym do mnemotechniki gestów, kostiumów oraz emblematów. Wielu badaczy etosu rycerskiego powiada o konstytutywnej dlań etyce walki leżącej poza pragmatycznymi bądź funkcjonalnymi aspektami życia społeczno-kulturowego, dzięki cementowaniu poszczególnych rytuałów odtwarzającego ów kontakt z autentycznym doświadczeniem sakralno-ludycznym przeżywanym przez bezpośrednich uczestników jambicznego agonu greckiego. W średniowiecznym świecie rycerskim autentyczność opisywanego doświadczenia w wielu przypadkach bywa już, niestety, kwestią mitu, w zamian osuwając się w formalną próżnię dworskiego konwenansu. Warto przy tej okazji przypomnieć, że pierwsze parodie mitycznych opowieści religijnych, ewokujące mimetyczne przejawy potężnego śmiechu dionizyjskiego, dochodzą do głosu jeszcze w wyrosłej z archaicznej światoprzestrzeni komedii staroattyckiej. Wspomniany śmiech dionizyjski jako katalizator patosu spod znaku Ajschylosa czy Arystofanesa odsyła do turnieju obelg, gefiryzmów, czyli ,żartów mostowych”, oraz zagadek, których transfiguracji należy upatrywać tak w agonie rycerskim, jak i literackim ${ }^{22}$. U Blooma, jak pamiętamy, ów rewizyjny interwał nosi miano demonizacji, rodzi się zaś z założycielskiego doświadczenia zazdrości o cudzą sławę (choć może mieć lżejszą realizację - w postaci przekomarzania się adwersarzy). Znawczyni tematu przypomina, iż „od rycerza oczekiwano, by był nieustannie zaprzątnięty własną sławą" (Ossowska, 1986, 81), oczywistą wobec tego konsekwencją tej aktywności jest, podobnie jak w przypadku

${ }^{22}$ „Drwiny i przycinki o charakterze osobistym - [...] to jeden z głównych korzeni komedii attyckiej. Miały one przeważnie formę wierszową jambiczną, a forma ta tak zrosła się z ich treścią, że charakterystyczną cechą poezji jambicznej stała się dla starożytnych osobista inwektywa i satyryczne ataki nie na pewne typy i typowe przywary ludzkie, ale na konkretne jednostki” (Srebrny, 1955, 8-9). Gefiryzmy [od grec. gephyra, czyli „most”) mają swoje źródło w pochodzie z Aten do Eleusis, odbywanym w ramach Misteriów Eleuzyńskich obchodzonych ku czci Demeter. Ów niezwykle demokratyczny (zrzeszał także niewolników) pochód wiódł przez most nad rzeką Kefisos, na którym lokalni żartownisie atakowali uczestników pochodu rozmaitymi uszczypliwościami. 
terminującego w fachu literackim efeba, troska o nieśmiertelność. „Być wiernym w dążeniu do chwały $\mathrm{i}$ - poprzez nią - do nieśmiertelności. Oto (z grubsza), czym jest etos rycerski” (Piwowarczyk, 1998, 165), potwierdza opinia innego badacza.

W propagowanym z kolei przez rycerski repertuar wartości kulcie starych wojowników, w których panteonie zasiadają waleczni bohaterowie Homeryckich eposów, dostrzec można dyskretną korespondencję łączącą ów kult ze zrekontekstualizowanym przez twórcę How to Read and Why zjawiskiem apophrades. Kontynuując czy naśladując czyny dawnych mistrzów, duchowych ojców, względnie kulturowych patronów (niezależnie od ich statusu, rzeczywistego bądź fikcyjnego), uczestniczy elitarnego stanu rycerskiego wnikają w sferę anachronicznej rywalizacji z duchami przodków. Ich sława istnieje właśnie dzięki owej kompulsywnej skądinąd potrzebie powtórzenia legendy, nad którą pragnie się przejąć władzę w imię dobra całej wspólnoty rycerskiej, świadomej konieczności stłumienia własnych, osobistych korzyści. W tym miejscu rodzi się okazja wysłowienia kilku uwag na temat fundamentalnej różnicy, jaka zachodzi między agonem rycerskim a literackim. W pasażach dedykowanych ludyczno-sakralnym korzeniom wojny archaicznej Huizinga wielokrotnie podkreśla, że „w etosie rycerskim ideał honorowej rywalizacji dotyczy wyłącznie równych sobie", zwracając przy tym uwagę na patriarchalny ciężar pragnienia zwycięstwa, które okazuje się ,zawsze silniejsze od narzuconego przez poczucie honoru ograniczenia" (Huizinga, 1998, 172), będącego conditio sine qua non bezinteresownej gry. W pojedynku literackim, warunkującym rozwój tej sztuki, relacja równości oznaczałaby śmierć inwencji, ilustrowanej przez Bloomowską rewizję, i ostatecznie osiągnęłaby unicestwiający pułap eschatonu. Życie literatury, jej osobliwa nieśmiertelność, gwarantowana jest zatem konstytutywnym brakiem równości miedzy prekursorem a adeptem.

$\mathrm{Na}$ osobną refleksję w obu komentowanych sytuacjach agonicznych zasługuje fenomen hojności, który na prawach ogólnej, jak zaznacza Georges Bataille, ekonomii odsyła do archaicznego zjawiska potlaczu (v. Mauss, 2001, 165 i n.) ${ }^{23}$. Bywa on najczęściej definiowany jako współ-

${ }^{23}$ Bataille przejmuje od Maussa zjawisko potlaczu i czyni zeń podstawę tego, co sam nazywa prawami ekonomii ogólnej. W myśl tych praw „Trzeba zatem, by dawać oznaczało 
zawodnictwo w rozdawaniu i niszczeniu swej własności bądź jako rywalizacja w trwonieniu dóbr. Hojność, oczekiwana od rycerza, emanująca zaś z uwodzącego niczym syreni śpiew dzieła prekursora, wpływa na charakter samego pojedynku, w którym gra toczy się o skalę narażania i trwonienia własności najcenniejszej, czyli samego życia, choć może ów pojedynek być postrzegany także jako wzajemne obdarowywanie się życiem. W obu przypadkach agonu wydaje się prawdziwe twierdzenie, w którym czytamy, że „Marnotrawstwo jest ostentacyjnym pozbywaniem się bogactwa w celu przypisania sobie dominującej pozycji względem innych" (Bataille, 2002, 82). Gwarancją zyskania tego, co Georges Bataille nazywa rangą, jest prawo do ostatniego słowa. Prawo pozostające w mocy nawet wówczas, gdy owo ostatnie słowo wydaje się słowem przywłaszczonym albo cudzym ${ }^{24}$.

\section{Na okoliczność braku konkluzji}

Swobodna forma eseju prowokuje, aby w miejsce tradycyjnej formuły zakończenia zaproponować odrębne rozwiązanie, w tym pojedynczym przypadku stawiające na kompozycję pierścienia czy genologiczną konwencję lirycznego ronda, na mocy których wypadnie powrócić do Kundery odpowiedzialnego za inicjalne frazy mojej opowieści, który w Nieśmiertelności niebezpośrednio potwierdza, że idea ludyczno-sa-

nabywać władzę. Dar ma właściwość przekraczania podmiotu ofiarowującego, lecz w zamian za ofiarowany przedmiot podmiot zawłaszcza przekroczenie: ocenia jego skuteczność, to, co dawało mu siłę, jako bogactwo, jako moc, która teraz do niego należy. Wzbogaca się, okazując pogardę dla bogactwa, pożąda natomiast efektów swej szczodrości. [...] Właśnie oddziaływanie na bliźniego stanowi o mocy daru, jakiej nabywa się poprzez utratę. Modelowy atrybut potlaczu zawarty jest w owej możliwości, jaką posiada człowiek, by pochwycić to, co mu się wymyka, by pogodzić bezgraniczny ruch wszechświata z ograniczeniami, które są jego udziałem" (Bataille, 2002, 78-79).

${ }^{24}$ Fenomen ostatniego słowa jest jedną z zabezpieczających iluzji, którymi krzepi się współczesna podmiotowość, ale, jak przekonuje Michail Bachtin i jego postmodernistyczni kontynuatorzy, każde słowo (nie wyłączając tego ostatniego) jest wypadkową cudzo-swojego bycia w języku, z którego nadzwyczaj piękną reprezentacją spotykamy się w literaturze, pojmowanej jako reprezentacja związków i relacji między doświadczeniem tekstualnym a doświadczeniem czytelnika, między ,życiopisaniem” prekursora a „życiopisaniem" adepta. 
kralnej gry z dziełami prekursorów jest mu szczególnie bliska. W przeciwieństwie, trzeba rzecz tę powiedzieć, do absolutnie poważnego, elegijnego tonu, jakim zawodzi Bloomowska teoria lęku przed wpływem. Pochylając się w trosce, której szczerość podminowana jest ironiczną energią, nad losem własnego pośmiertnego wizerunku, twórca Nieznośnej lekkości bytu w pewnym momencie wyznaje (miarą zaś tego wyznania jest dyskretna czułość, którą ów fragment w czytelniku wyzwala):

\begin{abstract}
Nie znam na świecie pisarza, który byłby mi droższy nad Roberta Musila. Umarł on pewnego ranka, gdy ćwiczył z hantlami. Kiedy i mnie zdarza się nimi ćwiczyć, lękliwie czuwam nad swoim pulsem i boję się umrzeć, gdyż śmierć z hantlami w ręku, jak śmierć mojego ukochanego autora, uczyniłaby ze mnie epigona tak niewiarygodnego, tak gorączkowego, tak fanatycznego, że śmieszna nieśmiertelność zostałaby mi zapewniona w jednej chwili (Kundera, 1995, 54 ).
\end{abstract}

\title{
Literatura
}

Arystofanes (1955). Wybór komedii. Przeł. i oprac. S. Srebrny. Warszawa: PIW.

Bataille, G. (2002). Część przeklęta oraz Ekonomia na miarę wszechświata. Granica użtecznego. Przeł. K. Jarosz. Warszawa: Wydawnictwo KR.

Bennett, M.J. (2013). Deleuze and Epicurean Philosophy. Atomic Speed and Swerve Speed. „Journal of French and Francophone Philosophy” vol. XXI, no 2, s. 131$-157$.

Bieńczyk, M. (2012). Książka twarzy. Warszawa: Świat Książki.

Bieńczyk, M. (2015). Przezroczystość. Warszawa: Wielka Litera.

Blanchot, M. (2004). Przyjaźń. Przeł. P. Mościcki. „Arterie” nr 1, s. 34-56.

Bloom, H. (1975). Kabbalah and Criticism. New York: Continuum.

Bloom, H. (1991). Ruin the Sacred Truths. Poetry and Belief From the Bible to the Present. Cambridge (Massachusetts) - London: Harvard University Press.

Bloom, H. (1995). The Western Canon. The Books and School of the Ages. London: Harcourt Brace.

Bloom, H. (2002). Lęk przed wpływem. Teoria poezji. Tłum. A. Bielik-Robson, M. Szuster. Kraków: TAiWPN Universitas.

Bloom, H. (2003). A Map of Misreading. Oxford \& New York: Oxford University Press.

Bobryk, J. (2011). Daimonion Sokratesa, neuroza Kierkegaarda, szaleństwo Nietzschego. Psychologia twórczości naukowej, metodologia badań naukowych. „Zagadnienia Naukoznawstwa" nr 1, s. 29-39.

Carus, T.L. (1994). O naturze rzeczy. Przekł., wst., kom. G. Żurek. Warszawa: PIW. 
Freud, Z. (1998). Kultura jako źródto cierpień. Przeł. R. Reszke. W: Z. Freud. Dzieła, t. 4: Pisma społeczne. Przeł. A. Ochocki, M. Poręba, R. Reszke. Oprac. R. Reszke. Warszawa: Wydawnictwo KR.

Gadamer, H.-G. (1993). Aktualność piękna: sztuka jako gra, symbol i święto. Przeł. K. Krzemieniowa. Warszawa: Oficyna Naukowa.

Garber, M. (2010). Shakespeare's Ghost Writers. Literature as Uncanny Causality. New York - London: Routledge.

Grabarczyk, K.M. (2013). „Simulacrum” Lukrecjusza w świetle wspótczesnej teorii metafory pojęciowej. Iuvenillia Philologorum Cracoviensium, t. VI: Źródta Humanistyki Europejskiej 6. Kraków: Wydawnictwo Naukowe UJ, s. 67-93.

Gudaniec, E. (brw.). Lukrecjusz (Titus Lucretius Carus). www.ptta.pl/pet/pdf/Lukrecjusz.pdf. 18.11.2018.

Huizinga, J. (1998). Homo ludens. Zabawa jako źródto kultury. Przeł. M. Kurecka, W. Wirpsza. Warszawa: Czytelnik.

Illg, J. (1990). Kilka uwag o sztuce powieściowej kompozycji Milana Kundery. „Literatura na Świecie" nr 9, s. 95-102.

Korpanty, J. (1991). Lukrecjusz. Rzymski apostot epikureizmu. Warszawa: Zakład Narodowy im. Ossolińskich.

Kundera, M. (1995). Nieśmiertelność. Przeł. M. Bieńczyk. Warszawa: PIW.

Kundera, M. (2004). Sztuka powieści. Esej. Wyd. II zmienione. Przeł. M. Bieńczyk, Warszawa: PIW.

Lipszyc, A. (2007). Dwóch wspótczesnych ironistów. „Nowa Krytyka” nr 14, s. 247-268 .

Man, P. de (1999a). Retoryka tropów (Nietzsche). Przeł. A. Przybysławski. „Teksty Drugie" nr 4, s. 193-205.

Man, P. de (1999b). Pojęcie ironii. Przeł. A. Sosnowski. „Literatura na Świecie” nr 10/11, s. 329-340.

Man, P. de (2004). Alegorie czytania. Język figuralny u Rousseau, Nietzschego, Rilkego i Prousta. Przeł. A. Przybysławski. Kraków: Universitas.

Mauss, M. (2001). Szkic o darze. Forma i podstawa wymiany w społeczeństwach archaicznych. W: M. Mauss. Socjologia i antropologia. Przeł. K. Pomian. Warszawa: Wydawnictwo KR.

McGushin, E.F. (2007). Foucault's Askesis. An Introduction to the Philosophical Life. Evanston: Northwestern University Press.

Oord, T.J. (2010). Essential Kenosis. W: T.J. Oord. The Nature of Love. A Theology. St. Louis, Missouri: Chalice Press.

Ossowska, M. (1986). Ethos rycerski i jego odmiany. Warszawa: Wydawnictwo Naukowe PWN.

Piwowarczyk, D. (1998). Obyczaj rycerski w Polsce późnośredniowiecznej (XIV-XV wiek). Warszawa: Wydawnictwo DiG.

Pycka, W. (brw.). Daimonion - boskie tknięcie. hektor.umcs.lublin.pl/-enkrateia/strony/czytelnia/dane/Daimonion.pdf. 18.11.2018.

Royle, N. (2003). The Uncanny. Manchester: Manchester University Press. 
Sławiński J. (red.) (2000). Słownik terminów literackich. Wrocław: Zakład Narodowy im. Ossolińskich.

Srebrny, S. (1955). Wstęp. W: Arystofanes. Wybór komedii. Przeł. i oprac. S. Srebrny. Warszawa: PIW.

Stevens, W. (1997). Collected Poetry and Prose. New York: Penguin Books.

Stevens, W. (2008). Żółte popołudnie. Wyb., przekł. i posł. J. Gutorow. Wrocław: Biuro Literackie.

Szturc, W. (1992). Ironia romantyczna: pojęcie, granice, poetyka. Warszawa: Wydawnictwo Naukowe PWN. 